\title{
Problem-Based Approach to Develop Creative Thinking in Students Majoring in Mathematics at Teacher Training Universities
}

\author{
Kateryna Vlasenko ${ }^{1}$, Vitaliy Achkan ${ }^{2}$, Olena Chumak ${ }^{3, *}$, Iryna Lovianova ${ }^{4}$, Tetiana Armash ${ }^{4}$ \\ ${ }^{1}$ Department of Mathematics and Modeling, Donbas State Engineering Academy, Ukraine \\ ${ }^{2}$ Department of Mathematics and Methods of Learning Mathematics, Berdyansk State Pedagogical University, Ukraine \\ ${ }^{3}$ Department of General Engineering, Donbas National Academy of Civil Engineering and Architecture, Ukraine \\ ${ }^{4}$ Department of Mathematics and Methods of its Training, Kryvyi Rih State Pedagogical University, 50000, Kryvyi Rih, Ukraine
}

Received March 15, 2020; Revised May 6, 2020; Accepted May 13, 2020

Copyright $(2020$ by authors, all rights reserved. Authors agree that this article remains permanently open access under the terms of the Creative Commons Attribution License 4.0 International License

\begin{abstract}
This paper looks into the issue of implementing problem-based approach to developing creative thinking in students majoring in Mathematics at teacher training universities. The object of the study is the process of developing creative thinking in students, majoring in Mathematics at teacher training Universities, through task-based approach. The methods used in the present study are theoretical analysis of research papers and resources, as well as a survey, conducted among students and lecturers. This survey is aimed at determining distinctive features of the problems in Elementary Mathematics, which can help to develop creative thinking in students. The aim of this study is to introduce the syllabus of the online-course "Creative Thinking through Teaching Elementary Mathematics" and to design a system of Open-ended and Integrative Problems in order to develop the components of creative thinking in students, majoring in Mathematics at teacher training universities. The tasks of the present study: to determine what key components of creative thinking in students majoring in Mathematics can be developed, when teaching Elementary Mathematics to them; to determine distinctive features of the Rich Tasks that will contribute to developing creative thinking in students in the course of teaching Elementary Mathematics to them; to introduce the syllabus of the online-course "Creative Thinking through Teaching Elementary Mathematics"; to design a system of rich tasks for arranging the learning process.
\end{abstract}

Keywords $\quad$ Creative
Mathematics, Mathematics Students, Rich Tasks,
Open-ended Problems, Integrative Problems, An On-line
Course, A Syllabus

\section{Introduction}

\subsection{Problem Statement and Justification of Its Relevance}

The issue of developing and enhancing creative thinking in students of different ages has always been of scientific and practical interest for both, researchers and academic staff.

As it is stated in Standards for preparing teachers of Mathematics, developed by the Association of Mathematics Teacher Educators [1] mathematics teachers must contribute to the development of creative thinking in students (Indicator C.3.1. Anticipate and Attend to Students' Thinking About Mathematics Content). The developers of Standards (Indicator P.3.1. Address Deep and Meaningful Mathematics Content Knowledge) refer mathematical problems to key tools for the development of such type of thinking and state, that it is crucial to do a research into the efficiency of selecting a system of tasks, into how they comply with the current trends in mathematics education, as well as into how positive students' perception of certain tasks is in course of studying Mathematics.

This idea is in line with the conclusions by Allen et al. [2] and Sullivan [36], who highlight the importance of selecting and systematizing the math problems, used in the learning process, given that students' opinions and expectations are taken into account. The researchers in the aforementioned papers consider that developing creative thinking in students must start in the first year of study at university, when teaching Mathematics: on the one hand, a mathematical problem must be used as a key object of studying and on the other - as a means of studying. 
Elementary Mathematics is one of the most important branches of Mathematics, and is the foundation for training mathematics students at teacher training universities, which is substantiated by Vlasenko et al. [4], stating that it is this subject that ensures revision, generalization and broadening students' knowledge of mathematical definitions and facts, which students were taught at school. The objective of the subject is also to develop would-be teachers' abilities and skills and teach them to apply those skills to practice. The above mentioned justifies timeliness and relevance of the issues of systematizing math problems, solving which will contribute to developing creative thinking in students when teaching Elementary Mathematics.

This article is aimed at undertaking a theoretical analysis of the resources focusing on the development of creative thinking in mathematics students at teacher training universities, as well as on papers devoted to the use of the problem-based approach to teaching Elementary Mathematics; developing and introducing the syllabus of the online-course "Creative Thinking through Teaching Elementary Mathematics" and a system of Rich tasks for this course.

\subsection{Analysis of the Latest Researches and Publications}

A considerable volume of literature has been published on solving problems in teaching Mathematics. As it was emphasized by Dickman [5], there are more than 100 different definitions of creativity in various research papers. The author investigated the interconnection between creativity and wording of mathematical tasks in primary school.

Silver [6] also mentioned that there is a direct connection between students' creativity and the problems which they solve in the course of learning. The similar research concerning links between mathematical problems and creative thinking was conducted by Van Harpen and Sriraman [7] and Maharani [8], who considered the key components of creative thinking and provided guidelines on how to develop_them with the help of the search of geometrical problems. Kajander et al. [9] carried out a fundamental research into the issue of developing mathematical creativity of teachers and students through problems that_are built around creativity. Scientists focused on the critical role of problems in developing creative thinking in students.

The authors in this paper turned to the analysis of those publications for two reasons: firstly, in order to identify the ways to develop creative thinking in students, when teaching Mathematics and the role of a math problem in this process.

Secondly, it was a question of selecting and systematizing the math problems in the course of designing a syllabus for mathematics students. Renkl [10] considered the role of corrective tasks and exercises in order to deal with the students' mistakes and improve their level of mathematical competencies. Breen and O'Shea [11] looked into the process of systematizing and selecting mathematical problems for Master Students, which would aim at developing their mathematical thinking.

When seeking a method of research, the authors of the present study turned to a paper by Yeo [12], who offered a classification of mathematical problems depending on the learning objectives and an assessment method to deal with learning activity of students.

The project "Types of Problems in Teaching Mathematics" by Clarke and Roche [13] was also of the scientific and practical interest. Within the framework of this project a survey concerning the selection of types of problems, depending on learning objectives was undertaken among teachers. Sullivan [3] made a significant contribution by conducting surveys among students, targeted determining types of problems. He found out what kind of problems is interesting for students. A wider coverage of problems in the research paper by Allen et al. [2], dedicated to students' attitudes towards various methods of teaching Mathematics, among which there were mathematical problems, drew the attention of the authors of the present study as well.

Most scientists share the opinion that the usage and selection of problems when teaching Mathematics at secondary school or Higher Mathematics at University, involves the preliminary analysis and systematization of certain types of problems, depending on the goal which a teacher sets. Such an approach, as the experts (Allen et al. [2], Sullivan [3], Yeo [12]) think, helps to understand what types of problems will be more efficient for developing creativity and creative thinking in students, their ability to introduce and apply innovations to their work. Added to that, according to the findings by Vlasenko et al. [14], using such an approach would be appropriate for developing an online course on Elementary Mathematics.

During the international conference MATTEX 2016 [15] the idea to systematize and introduce special types of problems in Elementary Mathematics, aimed at developing creative thinking in students was presented by the authors of this study and discussed by the scholars and practitioners, who attended that conference.

\section{Materials and Methods}

The platform "Higher School Mathematics Teacher" [42] was used to conduct a survey among lecturers of Mathematics at Berdiansk State Teacher Training University, Kryvyi Rih State Teacher Training University, Donbass State Machine Building Academy, Donbas National Academy of Civil Engineering and Architecture, Volodymyr Dahl East-Ukrainian National University, Pavlo Tychyna Uman State Teacher Training University, 
Cherkassy State Technological University.

It was focused on using various types of mathematical problems when teaching Elementary Mathematics in order to develop creative thinking in students. Another survey was conducted among mathematics students to find out their opinions and expectations from various types of problems in teaching Elementary Mathematics. The analysis of the responses allowed the authors of this article to start the research into the respondents' current preferences. Thus, they found out the respondents' opinions on creative thinking and its key components, on the term "mathematical problem" and criteria for systematizing types of problems, which contribute to developing creative thinking in students. The existing teaching experience in using integrative and open-ended problems was also analysed.

The Deductive Approach to Content Analysis was applied to understand if it is possible to involve the task-based approach in order to develop creative thinking in students. While selecting the resources, the preference was given to the ones, which present the development of practical aspects of creative thinking, the usage of various types of problems and tools that enhance inherent creativity of students (Table 1). The work undertaken resulted in designing the online syllabus for teaching the discipline.

Table 1. The analysis of the resources, that present on-line courses, aimed at developing creative thinking.

\begin{tabular}{|c|c|}
\hline On-line courses & Using tasks \\
\hline $\begin{array}{c}\text { Udemy, } 50 \text { Drawing } \\
\text { Exercises: Improve Creativity } \\
\text { \& Creative Thinking [16] }\end{array}$ & $\begin{array}{ll}\text { - } & \text { case studies; } \\
\text { - } & \text { open-ended problems } \\
\end{array}$ \\
\hline $\begin{array}{c}\text { Creative Thinking: Innovative } \\
\text { Solutions to Complex } \\
\text { Challenges [17] }\end{array}$ & $\begin{array}{ll} & \text { case studies; } \\
\text { - } & \text { research problems; } \\
\text { - } & \text { problems aimed at } \\
& \text { integrating knowledge }\end{array}$ \\
\hline $\begin{array}{c}\text { European Schoolnet Academy, } \\
\text { Developing Creative Thinking } \\
\text { Skills in Practice [18] }\end{array}$ & $\begin{array}{ll} & \text { case studies; } \\
\text { - } & \text { problems aimed at } \\
& \text { integrating knowledge } \\
\end{array}$ \\
\hline $\begin{array}{l}\text { Austalian Curriculum, Critical } \\
\text { and Creative Thinking [19] }\end{array}$ & $\begin{array}{ll}- & \text { open-ended problems } \\
\text { - } & \text { problems aimed at } \\
\text { integrating knowledge }\end{array}$ \\
\hline $\begin{array}{l}\text { Universal class, Creative } \\
\text { Thinking [20] }\end{array}$ & $\begin{array}{ll}- & \text { open-ended problems } \\
\text { - } & \text { research problems; } \\
& \text { tasks aimed at integrating } \\
& \text { knowledge } \\
\end{array}$ \\
\hline $\begin{array}{l}\text { School Education Gate Way, } \\
\text { Creativity for the future: } \\
\text { promoting Critical Thinking } \\
\text { and Problem-Solving in the } \\
\text { classroom [21] }\end{array}$ & $\begin{array}{ll}\text { - } & \text { research problems; } \\
\text { open-ended problems }\end{array}$ \\
\hline $\begin{array}{c}\text { Coursera, } \\
\text { Creative-Thinking-Techniques } \\
\text {-and-tools-for-success [22] }\end{array}$ & $\begin{array}{ll}\text { - } & \text { case studies; } \\
\text { - } & \text { research problems }\end{array}$ \\
\hline
\end{tabular}

By using task-based approach to developing creative thinking in students, the authors of the above mentioned courses are targeted at solving various types of research problems: case studies, open-ended problems, research problems, problems that integrate knowledge in natural science subjects, different branches of Economics, etc. The analysis of the recommendations, developed by the experts (Table 1), contributed to working out the syllabus sections and the system of open-ended and integrative problems to develop the components of creative thinking in students majoring in Mathematics. Responses by students and lecturers helped the authors of this article to define a name for the on-line course "Creative Thinking through Teaching Elementary Mathematics"; theoretical analysis of problems in Elementary Mathematics and the respondents' answers added to the content of the sections of the course.

\subsection{The Syllabus}

To prepare the summary of the course, the authors of this article have considered the scientists' viewpoints on the notion "creative thinking". Silver [6], Dickman [5], Kajander et al. [9] regard it as a type of thinking, aimed at generating non-conventional ideas, digressing from conventional algorithms, solving problems faster. So, the conclusion is made by Maharani [8] that creative thinking promotes conscientious and active involvement of students into transforming and improving the learning environment, revealing and refining inner resources.

The analysis of the research, conducted by Harpen and Sriraman [7], Kajander et al. [9], Dickman [5], Treffinger et al. [23], Karasel et al. [24], as well as taking account of the responses by lecturers and students made it possible to formulate the course objective, which is to develop the components of creative thinking in mathematics students at teacher training universities:

- the ability to identify and state problems;

- the ability to generate numerous ideas;

- the flexibility - ability to generate various ideas;

- the novelty - ability to act in a non-conventional way;

- the ability to improve the object, to add details.

When arranging the learning process within the framework of the course, the emphasis is put on solving Elementary Mathematics problems aimed at developing creative thinking in students. In order to determine the type of tasks, researchers follow the position of Yeo [12], who divided the problems into Mathematically-Rich Tasks and Non-Mathematically-Rich Tasks, depending on the impact they have on the development of personal, creative features of students.

Problems, which give students an opportunity to "discover" new mathematical rules (definitions, patterns), to act in a non-conventional way, to develop creative thinking are known as Rich Tasks in Elementary Mathematics. Open-ended and integrative problems are considered to be the main types of Rich Tasks.

Summarising the findings by Frobisher [25], Orton and Frobisher [26], Becker and Shimada [27], the authors of 
this paper consider that an open-ended problem is a problem, which does not have a predefined provision (having excessive data or their lack) or the one, which has several solutions depending on how you interpret the provisions.

The course "Creative Thinking through Teaching Elementary Mathematics" means to use case studies, open-ended and research problems. When solving a case study, students have to select mathematical apparatus and to apply it properly to find a solution to a certain problem. Solving open-ended problems, students have to add a certain provision (provisions) to the existing ones, formulate the problem and solve it. Using research problems involves students singling out methods for solving the problem and applying the methods properly.

When choosing the tasks that will ensure the proper arrangement of the learning process within the framework of the course, some aspects of integrating mathematical knowledge into knowledge of other subjects were clarified. Following the findings by Starr [28], Schleigh et al. [29], An et al. [30], Williams et al. [31], who considered integrative teaching of Mathematics and other subjects, when running integrative lessons and designing integrative syllabi.

The opinion of Wraga [32], who believes that most issues that secondary school students have, result from their lack of understanding of connections between the subjects on the school curricula added value to the work on the present paper.

University students, majoring in Mathematics, tend to face similar issues. They don't always understand the importance of unity of knowledge in different branches of Mathematics and the role which Mathematics plays in other areas of knowledge.

Thus, the authors of this paper consider that one of the ways to cope with the problem is to use integrative problems. By an integrative problem, we mean a problem, which promotes integration of the students' knowledge of different branches of secondary school Mathematics and/or Mathematics, taught at University. Using such problems is believed to provide integration of knowledge of Mathematics into other subjects.

To design the course, three types of integrative problems were singled out:

1. Problems, solving which students understand the connections between content and definitions of separate branches of Mathematics, taught at school (for instance, between Algebra and Geometry).

2. Problems, solving which students understand the connections between Elementary Mathematics and branches of Higher Mathematics, which are studied in parallel or will be studied in future.

3. Problems, generated beyond the scope of Mathematics, but which require applying mathematical methods to solve.

Taking into consideration the types of the problems used in the course, the main requirement to the course users is knowledge of Elementary Mathematics, Algebra, Geometry, Mathematical Logic, and Mathematical Analysis. Therefore, the course is designed for the first-year university students, majoring in Mathematics.

\subsection{The System of Open-ended and Integrative Problems to Develop the Components of Creative Thinking}

Here are some examples of a developed system of Rich tasks (Table 2), which will be used in the on-line course "Creative Thinking through Teaching Elementary Mathematics". Open-ended and integrative problems are structured according to three levels of complexity. Thus, the designers of the system of tasks take into account different levels of mathematical competencies of students. Added to that, transition from solving easier problems to more complex ones contributes to developing several components of creative thinking, which was also considered. 
Table 2. The examples of a system of Open-ended and Integrative Problems to Develop the Components of Creative Thinking

\begin{tabular}{|c|c|c|}
\hline \multicolumn{2}{|c|}{$\begin{array}{l}\text { Components of creative thinking, } \\
\text { which are developed in the course of } \\
\text { solving the problems }\end{array}$} & Open-ended problems \\
\hline Flexibility & \multirow{3}{*}{$\begin{array}{l}\text { The } 1^{\text {st }} \\
\text { level }\end{array}$} & $\begin{array}{l}\text { Case study. You have a rope with knots, the distance between them is } 12,5 \text { and } 13 \text { metres. How to } \\
\text { build a right angle with the help of this rope? }\end{array}$ \\
\hline $\begin{array}{l}\text { The ability to improve the } \\
\text { subject, to add details }\end{array}$ & & $\begin{array}{l}\text { Open-ended problem. To fill the motorboat, the fishermen used } 50 \text { litres of fuel. On the } 1^{\text {st }} \text { day they } \\
\text { used } 20 \text { litres, on the second day.... Complement the provision with a fraction, make up two problems } \\
\text { and solve them. }\end{array}$ \\
\hline $\begin{array}{l}\text { The ability to identify and } \\
\text { state the problem }\end{array}$ & & $\begin{array}{l}\text { Research problem. Based on the analysis of the manuals in Elementary Mathematics and school } \\
\text { textbooks, determine the methods for solving rational equations, using these methods. Draft a table, } \\
\text { which consists of two columns (method, example of the equation) and fill it in with the examples, } \\
\text { designed by you and with the determined methods. }\end{array}$ \\
\hline Flexibility, novelty & \multirow{3}{*}{$\begin{array}{l}\text { The } 2^{\text {nd }} \\
\text { level }\end{array}$} & $\begin{array}{l}\text { Case study. You have a land plot, rectangular in shape, } 130 \mathrm{~m} \text { long and } 80 \mathrm{~m} \text { wide. How to plant trees } \\
\text { on this plot? }\end{array}$ \\
\hline $\begin{array}{l}\text { The ability to improve the } \\
\text { subject, to add details; } \\
\text { flexibility }\end{array}$ & & $\begin{array}{l}\text { Open-ended problem. The lateral sides of a trapezoid equal } 13 \mathrm{~m} \text { and } 5 \mathrm{~m} \text { respectively. Draft } 3 \text { tasks } \\
\text { of different levels of complexity, using these provisions (no more than } 1 \text { provision can be added). }\end{array}$ \\
\hline $\begin{array}{l}\text { The ability to identify and } \\
\text { state the problem, the ability } \\
\text { to improve the subject, to } \\
\text { add details }\end{array}$ & & $\begin{array}{l}\text { Research problem. Based on the analysis of the manuals in Elementary Mathematics and school } \\
\text { textbooks, determine the methods for solving trigonometric equations and approximate basics for } \\
\text { the activity, using these methods. }\end{array}$ \\
\hline $\begin{array}{c}\text { Flexibility, the ability to } \\
\text { generate a number of ideas, } \\
\text { novelty }\end{array}$ & \multirow{3}{*}{$\begin{array}{l}\text { The } 3^{\text {d }} \\
\text { level }\end{array}$} & Case study. Can an equilateral triangle be cut into equal pentagons? Justify your answer. \\
\hline Flexibility & & $\begin{array}{l}\text { Open-ended problem. A circle is inscribed into a right-angle prism, the sides of which equal } 8,9 \text { and } \\
10 \mathrm{~m} \text {. Draft as many problems of different levels of complexity as possible, using these provisions } \\
\text { (no more than } 2 \text { provisions can be added). }\end{array}$ \\
\hline $\begin{array}{l}\text { The ability to identify and } \\
\text { state the problem, flexibility, } \\
\text { the ability to improve the } \\
\text { subject, to add details }\end{array}$ & & $\begin{array}{l}\text { Research problem. Classify the types of problems in topic «Trigonometry», determine the key } \\
\text { methods (ways of solving } 2 \text { of the types of problems, which you offer). }\end{array}$ \\
\hline & & Integrative problems \\
\hline \multirow{3}{*}{$\begin{array}{l}\text { The ability to identify and } \\
\text { state the problem }\end{array}$} & \multirow{3}{*}{$\begin{array}{l}\text { The } 1^{\text {st }} \\
\text { level }\end{array}$} & $\begin{array}{l}\text { Problems, solving which enhances the students' understanding of the content and conceptual } \\
\text { connections between certain sections in Mathematics, taught at secondary school. } \\
2 \text { semidiametres of a circle divide it into arcs. The lengths of the arcs correlate as } 2: 4: 5 \text {. Find the } \\
\text { length of the bigger arc, if the circumference is } 44 \pi \mathrm{cm} \text {. }\end{array}$ \\
\hline & & $\begin{array}{l}\text { Problems, solving which enhances the students' understanding of the connections between } \\
\text { Elementary Mathematics and sections of Higher Mathematics. } \\
\text { Compare the numbers } \sqrt[1001]{1001} \mathrm{i} \sqrt[2019]{2018}\end{array}$ \\
\hline & & $\begin{array}{l}\text { Problems, generated beyond the scope of Mathematics, but solving which requires applying } \\
\text { mathematical methods. After how many half-life periods there will be } 8 \mathrm{~g} \text { of radioactive substance } \\
\text { left out of } 64 \mathrm{~g} \text { ? }\end{array}$ \\
\hline \multirow{2}{*}{$\begin{array}{l}\text { The ability to identify and } \\
\text { state the problem }\end{array}$} & \multirow{3}{*}{$\begin{array}{l}\text { The } 2^{\text {nd }} \\
\text { level }\end{array}$} & $\begin{array}{l}\text { Problems, solving which enhances the students' understanding of the content and conceptual } \\
\text { connections between certain sections in Mathematics, taught at secondary school. To calculate the } \\
\text { meaning of the mathematical formula } \log 14 \cos 675^{\circ} \text {. }\end{array}$ \\
\hline & & $\begin{array}{l}\text { Problems, solving which enhances the students understanding of the connections between } \\
\text { Elementary Mathematics and sections of Higher Mathematics. At what maximum positive value of } \\
\text { the parameter the length of vector } \tilde{n}(\dot{a} ; 3 ;-1) \text { will be less than } 5 \text { ? }\end{array}$ \\
\hline $\begin{array}{l}\text { The ability to identify and } \\
\text { state the problem, flexibility }\end{array}$ & & $\begin{array}{l}\text { Problems, generated beyond the scope of Mathematics, but solving which requires applying } \\
\text { mathematical methods. A ball with a mass of } m \text {, suspended on a string, is executing periodic } \\
\text { motion. When the ball is in an equilibrium state, the tension force of the string equals } T=2 m \text {. } \\
\text { What is the maximum angle } \alpha \text { of the deflection of the ball from the vertical position? }\end{array}$ \\
\hline \multicolumn{3}{|r|}{ The $3^{\mathrm{d}}$ level } \\
\hline \multirow{2}{*}{$\begin{array}{l}\text { The ability to identify and } \\
\text { state the problem, flexibility, } \\
\text { novelty }\end{array}$} & \multirow{3}{*}{$\begin{array}{l}\text { The } 3^{\text {d }} \\
\text { level }\end{array}$} & $\begin{array}{l}\text { Problems, solving which enhances the students' understanding of the content and conceptual } \\
\text { connections between certain sections in Mathematics, taught at secondary school. To calculate the } \\
\text { meaning of the mathematical formula }(\sqrt{21+8 \sqrt{5}}+\sqrt{21-8 \sqrt{5}})\end{array}$ \\
\hline & & $\begin{array}{l}\text { Problems, solving which enhances the students' understanding of the connections between } \\
\text { Elementary Mathematics and sections of Higher Mathematics. } \\
\text { Solve the equation } \sqrt{x-1}+\sqrt{9-x}=x^{2}-10 x+29 .\end{array}$ \\
\hline $\begin{array}{l}\text { The ability to identify and } \\
\text { state the problem, flexibility }\end{array}$ & & $\begin{array}{l}\text { Problems, generated beyond the scope of Mathematics, but solving which requires applying } \\
\text { mathematical methods. A bus is moving along a straight motorway at the speed of } 16 \mathrm{~m} \text { per sec. } \\
\text { There is a person in the field, } 60 \mathrm{~m} \text { away from the motorway and } 400 \mathrm{~m} \text { away from the bus. The } \\
\text { person can move at the speed of } 4 \mathrm{~m} \text { per sec. What direction should this person choose in order to } \\
\text { catch the bus? }\end{array}$ \\
\hline
\end{tabular}




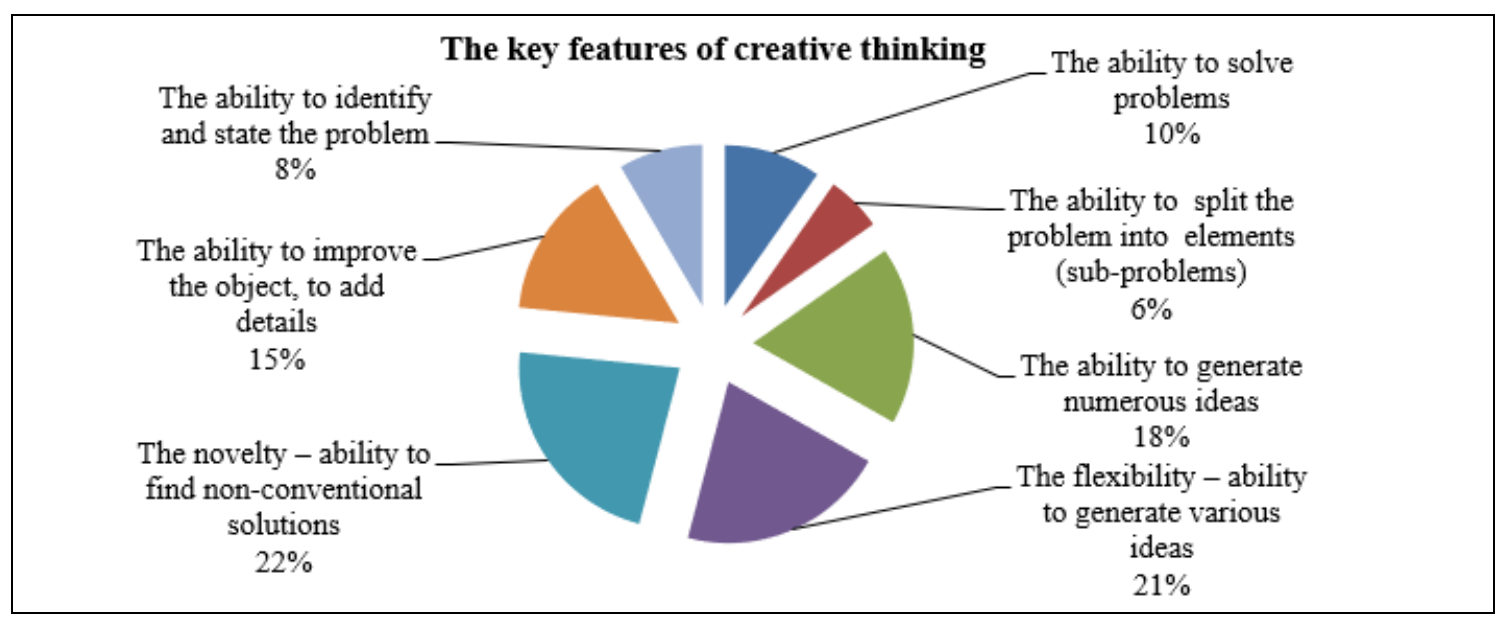

Figure 1. The key features of creative thinking according to the students' responses

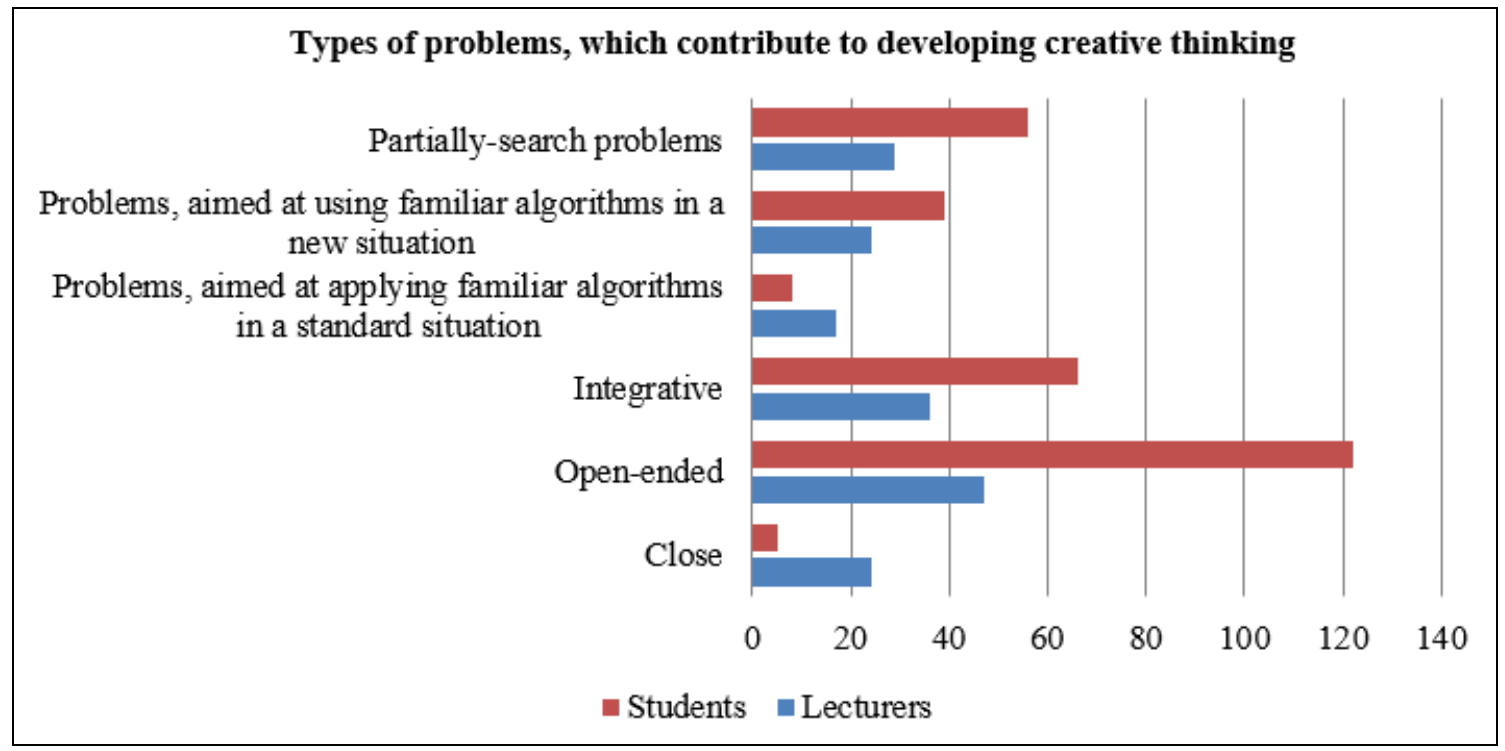

Figure 2. Types of problems, which contribute to developing creative thinking according to the opinions of lecturers and students

\section{Results}

To conduct the analysis, defined by the objective of the present research a survey on the platform "Higher School Mathematics Teacher" [42] was conducted. University lecturers and students were asked to express their opinions on applying task-based approach to developing creative thinking in students.

Another survey was conducted among mathematics students at teacher training universities in order to define the key features of creative thinking; types of problems in Elementary Mathematics which, in their opinion, will help enhance their creative thinking. In total 65 lecturers and 157 students at different universities were surveyed.
According to the students' responses (Figure 1), the key features of creative thinking are: the ability to generate a significant number of ideas, flexibility, novelty and ability to improve the object.

When systematizing the tasks for the arrangement of the learning process, researchers learnt from the students and the lecturers what types of problems (Figure 2), in their opinion, contribute to developing creative thinking.

Thus, the respondents' answers confirmed the expediency of using open-ended and integrative problems for arranging on-line learning. When systematizing the types of open-ended (Figure 3) and integrative (Figure 4) problems, researchers again focused on the opinion of the respondents - students and lecturers. 


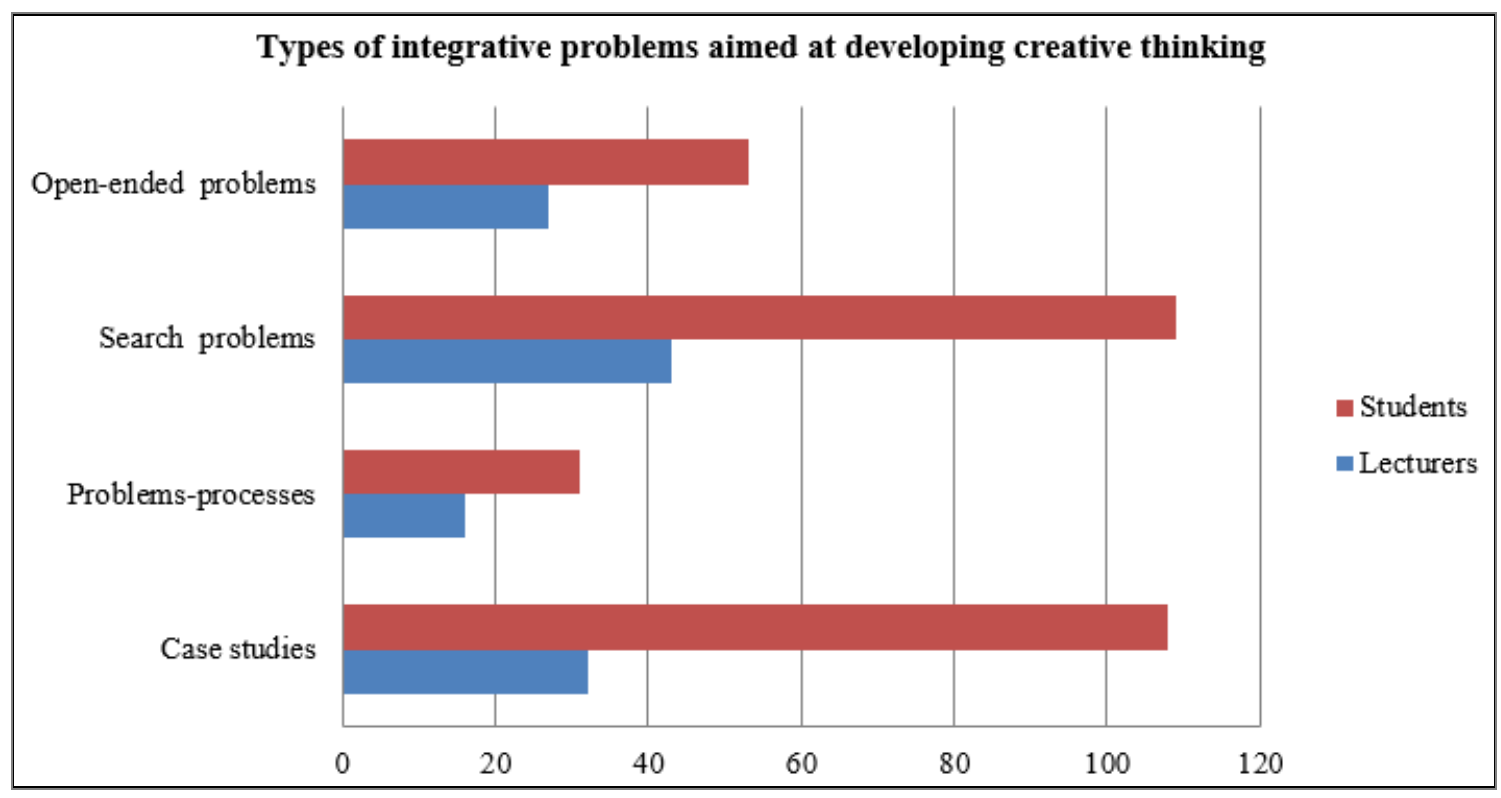

Figure 3. Types of integrative problems aimed at developing creative thinking

\section{Types of integrative problems aimed at developing creative thinking}

Problems, generated beyond the scope of Mathematics, but require applying mathematical methods

Problems, solving which promotes integration of Mathematical and methodological competencies

Problems, solving which contributes to establishing connections between Higher and Elementary Mathematics

Problems, solving which helps students establish connections between certain sections of Elementary Mathematics

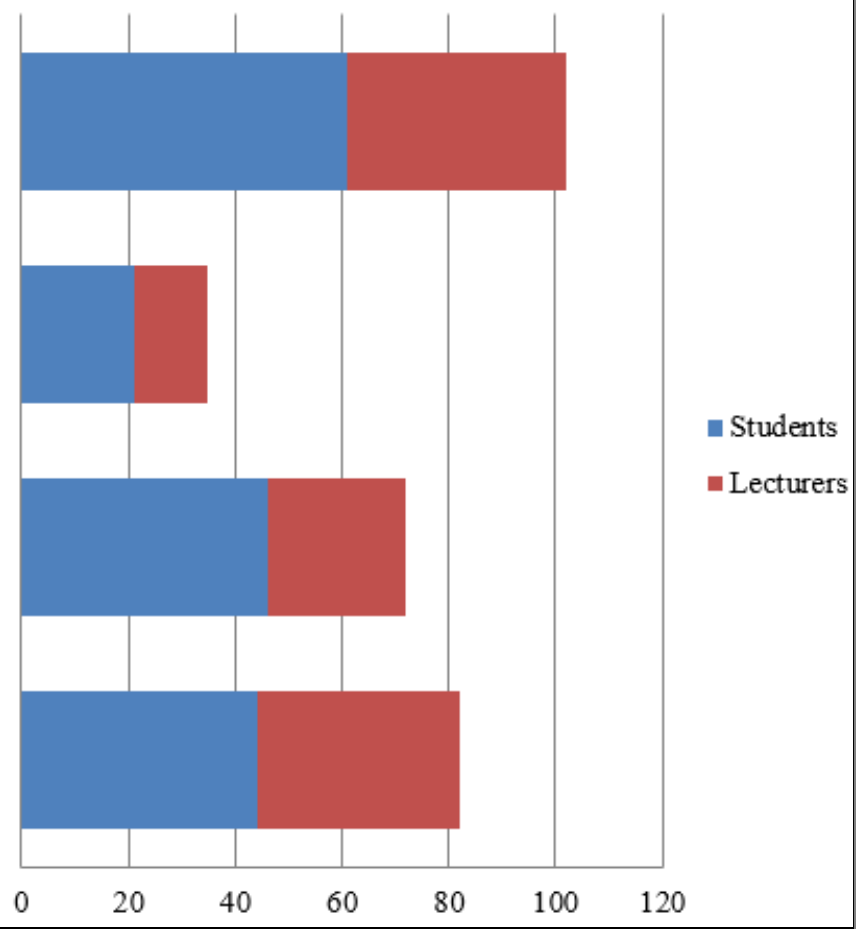

Figure 4. Types of integrative problems aimed at developing creative thinking

Thus, the respondents' answers confirmed the expediency of using open-ended problems, search problems, case studies. The most popular types of integrative tasks among the respondents were: problems, generated beyond the scope of Mathematics, but require applying mathematical methods, problems, solving thereof contributes to establishing connections between Higher and Elementary Mathematics or between sections of Elementary Mathematics.

Through being proactive and showing interest in the course, both the lecturers and the students helped to define the topics of the course "Creative Thinking through Teaching Elementary Mathematics", the content for the Syllabus sections, and the types of Rich tasks, which should be chosen to systematize. 


\section{Discussion}

In this article the authors share the opinion of Maharani [8], Papadakis et al. [33], Tezer et al. [34], who state that the role of creative thinking in the modern globalized world is becoming more important, as the competition is getting more tough and the problems which future mathematicians are to solve are becoming more sophisticated. Findings of the researchers (Dickman [5], Silver [6], Harpen and Sriraman [7], Kajander at el. [9]) prove the topicality and timeliness of introducing a problem-orientated approach to developing creative thinking in students. They also emphasize that to develop creative thinking is possible with the help of specially selected types of tasks.

Students must be given an opportunity to select types of problems, which they want to learn about while studying Elementary Mathematics, as Sullivan [3], Vlasenko et al. [35] emphasize. The researchers consider it feasible to design an on-line course, aimed at using selected types of problems for developing creative thinking in Mathematics students in teacher training Universities.

The idea to design the on-line course also complies with the conclusions, made by Zaranis et al. [36], Lin and Ying-Wei Wu [37], Hjalmarson [38], Perikos et al. [39], Lovianova et al. [40], that prove the efficiency of on-line education in order to develop creativity in students while teaching Mathematics. Henson et al. [41] consider Syllabi as a course map for any online course, so this statement was taken into account for the purpose of the present research.

All the information (findings, estimates, actions, and content), that is needed to design the course, was collected and evaluated to prepare a complete syllabus for online students before the start of the course. Students are also offered to have Elementary Mathematics training that helps them discover new possibilities and inner resources to create innovations, to develop their abilities to improve the object adding details, find non-conventional solutions, identify and state the problem, split the problem into sub-problems, generate numerous ideas.

Focusing on the research papers and taking account of the expectations of the future course users as to the arrangement of the learning process, open-ended and integrative problems were used by the authors of this paper, who strongly believe, that work with open-ended problems will contribute to developing key components of creative thinking (ability to generate ideas, offer non-conventional methods for solving the tasks, to refine their own proposal - a task, an idea, a product). Solving integrative problems will help students see Mathematics in the world around them, to find connections between different phenomena, using various methods when solving professional tasks and problems.

\section{Conclusions}

Nowadays, when information is most often shared via the Internet, informal education through on-line courses becomes more widespread. This fact determined and contributed to developing the system of Rich tasks in Elementary Mathematics and designing the syllabus of the online-course "Creative Thinking through Teaching Elementary Mathematics".

Analysis of academic papers and resources proved the relevance of researching into the issue of developing creative thinking in students who major in Mathematics in teacher training Universities. The Deductive Approach to Content Analysis of the resources made it possible to involve a problem-based approach to selecting topics, various types of tasks and tools that contribute to enhancing inherent human creativity and can be of practical interest for students.

The analysis done by the authors of the present paper helped determine the course syllabus sections and the methodology for providing the content for those sections. When developing the summary of the course, the experience of scholars and course experts must be a guideline, but in order to live up to students' expectations, it is advisable to conduct a survey among Mathematics students and lecturers. Therefore, when formulating the course objectives and selecting the tasks for the arrangement of the learning process, the respondents' opinions are to be taken into account.

The interpretation of the respondents' answers confirmed the importance of developing an online course and their willingness to learn about two types of Rich tasks in Elementary Mathematics: open-ended problems and integrative problems. The requirements for systematizing problems that are used within the framework of the course are to be clarified. These should be the problems that will help students generate new ideas, approach problem-solving in a non-conventional way, analyze all the possible options of the course of action, improve own proposals, establish connections between objects of different nature, see and apply Mathematics and its methods in the world around them, as well as in practical activity.

Given that solving such problems requires knowledge of the elements of Algebra, Geometry, Mathematical Logic, Mathematical Analysis, the course is designed for Mathematics students. It can also be used by those who want to find out how new ideas are generated and non-conventional paths of action are taken with the help of Elementary Mathematics. When systematizing the tasks, it is advisable to select the problems of different levels of complexity, in order to make the course accessible for the students, who have no proper mathematical background. Uploading materials of the on-line course "Creative Thinking through Teaching Elementary Mathematics" to the on-line educational platform "Higher School 
Mathematics Teacher" [42] is the focus of further research for the authors of this study. The direction for further research implies describing the implementation of the on-line course into practical training of the students majoring in Mathematics in teacher training universities.

\section{REFERENCES}

[1] Standards for preparing teachers of Mathematics, Association of Mathematics Teacher Educators, 2018. Online available from: https://amte.net/standards

[2] B. Allen. Pupils' perspectives on learning mathematics. In B. Allen \& S. Johnston-Wilder (Eds.). Mathematics education: Exploring the culture of learning. London: Routledge Falmer, 2004. Online available from: https://www.taylorfrancis.com/books/e/9780203465394

[3] P. Sullivan. Learning about selecting classroom tasks and structuring mathematics lessons from students, 2010. Online available from: https://research.acer.edu.au/cgi/vie wcontent.cgi? article $=1076 \&$ context $=$ research_conference

[4] K. Vlasenko, O. Chumak, I. Sitak, T. Kalashnykova, V. Achkan. CLIL Method to increase students' motivation in studying mathematics at higher technical school. Universal Journal of Educational Research, Vol. 8, No. 2, 362-370, 2020. Online available from: DOI: $10.13189 /$ ujer.2020.080 205

[5] B.M. Dickman. Conceptions of creativity in elementary school mathematical problem posing. Submitted in partial fulfillment of the requirements for the Degree of Doctor of Philosophy under the Executive Committee of the Graduate School of Arts and Sciences. Columbia University, 2014. Online available from: https://www.researchgate.net/profile/Benjamin_Dickman/p ublication/303913647_Conceptions_of_Creativity_in_Ele mentary_School_Mathematical_Problem_Posing/links $/ 575$ d2e0608aec91374ad55c7/Conceptions-of-Creativity-in-Ele mentary-School-Mathematical-Problem-Posing.pdf

[6] E.A. Silver. On Mathematical Problem Posing. For the learning of mathematics, 14(1), 19-28. 1994. Online available from:https://flm-journal.org/Articles/2A5D1527 78141F58C1966ED8673C15.pdf

[7] X.Y. Van Harpen \& B. Sriraman. Creativity and mathematical problem posing: an analysis of high school students' mathematical problem posing in China and the USA. Educational Studies in Mathematics, Vol. 82, No. 2, 201-221, 2013. Online available from: https://www.jstor.org/stable/23434869?seq=1

[8] H.R. Maharani. Creative thinking in mathematics: are we able to solve mathematical problems in a variety of way? International Conference on Mathematics, Science, and Education 2014 (ICMSE 2014), 2014. Online available from:

http://research.unissula.ac.id/file/publikasi/211313016/402 521.pdf

[9] A. Kajander, D. Manuel, B. Sriraman. Exploring creativity: from the mathematics classroom to the mathematicians' mind, 2016. Online available from: https://www.researchg ate.net/publication/324543387_Exploring_Creativity_Fro $\mathrm{m}$ the mathematics_classroom_to the mathematician $\% 2$ $7 \mathrm{~s}$ - mind

[10] A. Renkl. The significance of learning tasks and corrective feedback for achievement growth in mathematics, 2015. Online available from: https://www.researchgate.net/publi cation/29754758_The_significance_of_learning_tasks_and corrective_feedback_for_achievement growth_in mathe matics/related

[11] S. Breen, A. O'Shea. Mathematical thinking and task design Irish. Math. Soc. Bulletin, Vol. 66, 39-49, 2010. Online available from:https://www.researchgate.net/public ation/269005092_Mathematical_thinking_and_task_desig n

[12] J.B.W. Yeo. Mathematical tasks: clarification, classification and choice of suitable tasks for different types of learning and assessment. Mathematics and Mathematics Education technical report series, 2007. Online available from: http://citeseerx.ist.psu.edu/viewdoc/download?doi=10.1.1. $517.5875 \&$ rep $=$ rep $1 \&$ type $=$ pdf

[13] D. Clarke, A. Roche. Teachers' extent of the use of particular task types in mathematics and choices behind that use. In L. Sparrow, B. Kissane, \& C. Hurst (Eds.), Shaping the future of mathematics education (Proceedings of the 33rd annual conference of the Mathematics Education Research Group of Australasia). Fremantle, Western Australia: MERGA, 153-160, 2010. Online available from:https://pdfs.semanticscholar.org/f311/351d 1ae224b3dac5a5ee8918b8af9369157c.pdf

[14] K. Vlasenko, O. Chumak, I. Sitak, O. Chashechnikova, I. Lovianova, I. Developing informatics competencies of computer sciences students while teaching differential equations. Revista ESPACIOS, 40 (31), 11, 2019. Online available from:

http://www.revistaespacios.com/a19v40n31/19403111.htm

[15] V.V. Achkan, N.V. Kugay. Methodological knowledge in elementary mathematics as groundwork for developing readiness for innovative educational activity in future mathematics teachers. "MATTEX 2016", Vol. 1, 226-235, 2016. Online available from: https://zenodo.org/record/264 010\#.X1QhLPRwm1s

[16] Udemy, 50 Drawing Exercises: Improve Creativity \& Creative Thinking Online available from: https://www.udemy.com/course/doodle-drawing-exercisesimprove-your-creativity-creative-thinking/?gclid $=\mathrm{CjwKC}$ AiAjMHwBRAVEiwAzdLWGEpWH2DKCNZty7GVMC qEs-hAbz0HwZ1nqrrT4K_t5fIh3gxJuJsjhoCwLkQAvD_ BwE\&matchtype $=b \& u t m$ campaign $=$ LongTail la.EN cc. ROW\&utm_content $=$ deal $\overline{4} 584 \&$ utm medium $=\overline{\text { udemyads }}$ \&utm source $=$ adwords\&utm term $=$. ag 78754135813 . ad_386819501951_.kw_\%2Bcreative $+\%$ 2Bthinking $+\overline{\%}$ 2Bcourse_.de_c_.dm_._pl_.ti_kwd-459487938937_. _li_1030487..pd_..

[17] Creative Thinking: Innovative Solutions to Complex Challenges. Online available from:https://www.extension. harvard.edu/professional-development/programs/creative-t hinking-innovative-solutions-complex-challenges

[18] European Schoolnet Academy. Developing Creative 
Thinking Skills in Practice - are my students learning to creatively solve problems? Online available from: https://www.europeanschoolnetacademy.eu/courses/course -v1:TeachUP+TU4_Creative_EN+2019/about

[19] Austalian Curriculum. Critical and Creative Thinking. Online available from: https://www.australiancurriculum.e du.au/f-10-curriculum/general-capabilities/critical-and-cre ative-thinking/

[20] Universal class. Creative Thinking. Online available from: https://www.universalclass.com/i/course/creative-thinking. htm

[21] School Education Gate Way. Creativity for the future: promoting Critical Thinking and Problem-Solving in the classroom. Online available from: https:/www.schooledu cationgateway.eu/en/pub/teacher_academy/catalogue/detai 1.cfm?id=85064

[22] Coursera

Creative-Thinking-Techniques-and-tools-for-success.

Online available from: https://ru.coursera.org/learn/creativ e-thinking-techniques-and-tools-for-success

[23] D.J. Treffinger, G.C. Young, E.C. Selby, C. Shepardson. Assessing creativity: A guide for educators. The National Research Center on the Gifted and Talented (NRC/GT), 2002. Online available from: https://files.eric.ed.gov/fullte $\mathrm{xt} / \mathrm{ED505548.pdf}$

[24] N. Karasel, O. Ayda, M. Tezer. The relationship between mathematics anxiety and mathematical problem solving skills among primary school students. Procedia-Social and Behavioral Sciences, 2(2), 5804-5807, 2010. Online available from: https://www.researchgate.net/publication/2 48607031 The relationship between mathematics anxiet y_and_mathematical_problem_solving_skills_among_pri

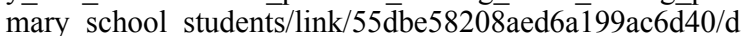
ownload? doi: 10.1016/j.sbspro.2010.03.946

[25] L. Frobisher. Problems, investigations and an investigative approach. In A. Orton \& G. Wain (Eds.), Issues in teaching mathematics. London: Cassell, 150-173, 1994. Online available from: https://www.amazon.com/Issues-Teaching -Mathematics-Cassell-Education/dp/0304326801

[26] A. Orton, L.J. Frobisher. Insights into teaching mathematics. London; New York: Cassell, 1996. Online available from: https://books.google.com.ua/books?id=esGvAwAAQBAJ $\& p g=$ PA $183 \& \operatorname{lpg}=$ PA $183 \& d q=I n+A .+$ Orton $+\% 26+\mathrm{G} .+\mathrm{W}$ ain $+($ Eds. $),+$ Issues + in + teaching + mathematics\&source $=b 1$ \&ots $=$ kkhS8J39q7\&sig=ACfU3U1Rc_gpVNy5tlG28CptD frlu-2KIg\&hl=ru\&sa=X\&ved=2ahUKEwjlnozPi-vnAhUT i8MKHfxqBX8Q6AEwAHoECAcQAQ\# $\mathrm{v}=$ onepage \&q=In $\% 20$ A.\%20Orton\%20\%26\%20G.\%20Wain\%20(Eds.) $\% 2 \mathrm{C}$ $\%$ 20Issues \%20in\%20teaching\%20mathematics\&f=false

[27] J.P. Becker \& S. Shimada. The open-ended approach: A new proposal for teaching mathematics. Reston, VA: National Council of Teachers of Mathematics, 1906 Association Drive, Reston, 1997. Online available from: https://eric.ed.gov/?id=ED419689

[28] L. Starr. The administrator's role in technology integration. Education World, 2009. Online available from: http://www.educationworld.com/a tech/tech087.shtm

[29] S. Schleigh, M. Bossé, T.D. Lee. Redefining curriculum integration and professional development: In service teachers as agents of change. Current Issues in Education, Vol.14, No. 3, 1-13, 2011. Online available from: https://www.semanticscholar.org/paper/Redefining-Curric ulum-Integration-and-Professional-Schleigh-Boss $\% \mathrm{C} 3 \% \mathrm{~A}$ 9/6752dc54b80af76d615e6cec1bf89be4dca83dd8

[30] S. An, M.M. Capraro, D.A. Tillman. Elementary teachers integrate music activities into regular mathematics lessons: Effects on students' mathematical abilities. Journal for Learning through the Arts: A Research Journal on Arts Integration in Schools and Communities, Vol. 9, No.1, 2013. Online available from: https://files.eric.ed.gov/fullte xt/EJ1018326.pdf

[31] J. Williams, W.-M. Roth, D. Swanson. Interdisciplinary mathematics education: A state of the art. In: Interdisciplinary Mathematics Education. ICME-13 Topical Surveys. Springer, Cham, 1-36, 2016. Online available from: https://www.walmart.com/ip/Interdisciplin ary-Mathematics-Education-A-State-of-the-Art-978331942 $2664 / 53930800$

[32] W.G. Wraga. Toward a connected core curriculum. Educational Horizons, Vol. 87, No. 2, 88-96, 2009. Online available from:https://files.eric.ed.gov/fulltext/EJ826479.p df

[33] St. Papadakis, M. Kalogiannakis \& N. Zaranis. Improving Mathematics Teaching in Kindergarten with Realistic Mathematical Education. Early Childhood Education Journal, 45(3), 369-378, 2016. Online available from: ttps://www.researchgate.net/publication/289586063 Impro ving Mathematics Teaching in Kindergarten with Reali stic Mathematical Education/link/5919a4030f7e9b1db65 264d 7/download?doi: 10.1007/s10643-015-0768-4

[34] M. Tezer, D. Onbasi, H. Falyali Examination of The Learning Strategies Used By Secondary School Students Towards A Mathematics Course In Terms Of Certain Variables. II OAB JOURNAL, 9(3), 144-151, 2018. Online available from:https://www.iioab.org/IIOABJ 9.S3 144-1 51.pdf

[35] K. Vlasenko, I. Lovianova, I. Sitak, O. Chumak, O. Kondratyeva. Training of mathematical disciplines teachers for higher educational institutions as a contemporary problem. Universal Journal of Educational Research, Vol. 7, No. 9, 1892 - 1900, 2019. Online available from: doi: 10.13189/ujer.2019.070907.

[36] N. Zaranis, M. Kalogiannakis \& S. Papadakis. Using Mobile Devices for Teaching Realistic Mathematics in Kindergarten Education. Creative Education (Special Issue in Preschool Education), 4(7Á1), 1-10, 2013. Online available from: https://www.researchgate.net/publication/2 48386933 Using Mobile Devices for Teaching Realisti c_Mathematics_in_Kindergarten_Education/link/0046351 de $6 \mathrm{~d} 3$ bcc $03400000 \overline{0}$ /download? $\overline{\mathrm{d}} \mathrm{i}$ : 10.4236/ce.2013.47A1001

[37] Cheng-Shih Lin, Ryan Ying-Wei Wu. Effects of web-based creative thinking teaching on students' creativity and learning outcome. Eurasia Journal of Mathematics, Science \& Technology Education, Vol. 12, No. 6, 1675-1684, 2016. Online available from:https://doi.org/10.12973/eurasia.20 $16.1558 \mathrm{a}$

[38] M.A. Hjalmarson. Learning to teach mathematics specialists in a synchronous online course: a self-study. Journal of Mathematics Teacher Education, Vol. 20, 
281-301, 2017. Online available from: https://link.springe r.com/article/10.1007/s10857-015-9323-x

[39] I. Perikos, F. Grivokostopoulou, K. Kovas and I. Hatzilygeroudis. Assisting tutors to utilize Web 2.0 tools in education', International Conference e-Learning, 121-128, 2015. Online available from: https://pdfs.semanticscholar. org/5d28/d66574236671b658a413f510b22f90d3f37a.pdf

[40] I. Lovianova, K. Vlasenko, A. Krasnoschok, D. Dmytriiev, R. Shponka. Modeling of ICT Competence Formation of Would-be Mathematics Teacher. Information Technologies and Learning Tools, Vol. 74, No. 6, 2019. Online available from: https://journal.iitta.gov.ua/index.ph p/itlt/article/view/2421

[41] H.A. Henson, J.A. McWherter, D. McKitrick, D.W. Morris. Best practices for teaching online: Creating an online syllabus, Online available from:http://ux1.eiu.edu/ warobi nson/UT_Creating\%20an\%20Online\%20Syllabus.pdf, last accessed 2020/01/19.

[42] Higher School Mathematics Teacher, 2019. Online available from: http://formathematics.com/courses/imt/ope $\mathrm{n}$-and-integrated-tasks-of-elementary-mathematics/ 